\title{
Pengaruh Jumlah Angkatan Kerja dan Investasi terhadap Pendapatan Asli Daerah
}

\section{The Impact of Labor Number and Investment on Original Local Government Revenue}

\author{
Reza Tianto \\ Fakultas Ekonomi dan Bisnis, Universitas Hayam Wuruk Perbanas Surabaya, Kota Surabaya \\ e-mail korespondensi: reza.tianto@perbanas.ac.id
}

\begin{tabular}{|c|c|}
\hline Info Artikel & Abstrak \\
\hline $\begin{array}{l}\text { Riwayat Artikel: } \\
\text { Diterima: } 08 \text { Agustus } 2021 \\
\text { Disetujui: } 18 \text { September } 2021 \\
\text { Dipublikasikan: Januari } 2022\end{array}$ & $\begin{array}{l}\text { Tujuan penelitian ini yaitu menganalisa pengaruh dari jumlah angkatan kerja dan } \\
\text { investasi terhadap Pendapatan Asli Daerah (PAD). PAD provinsi di Indonesia } \\
\text { memiliki angka yang berbeda-beda setiap provinsinya. Setiap tahunnya angka } \\
\text { PAD berfluktuasi dan membentuk pola tertentu setiap masing-masing provinsi. }\end{array}$ \\
\hline $\begin{array}{l}\text { Nomor DOI } \\
\text { 10.33059/jseb.v13i1.3982 } \\
\text { Cara Mensitasi : } \\
\text { Tianto, R. (2022). Pengaruh } \\
\text { jumlah angkatan kerja dan } \\
\text { investasi terhadap pendapatan } \\
\text { asli daerah. Jurnal Samudra } \\
\text { Ekonomi dan Bisnis, } 13(1), \\
\text { 113-124. doi: } 10.33059 / \text { jseb. } \\
\text { v13i1.3982. }\end{array}$ & $\begin{array}{l}\text { Jumlah angkatan kerja dan investasi diestimasi mempengaruhi besaran angka } \\
\text { PAD. Data penelitian menggunakan data dari } 34 \text { provinsi di Indonesia yang } \\
\text { diambil dari Badan Pusat Statistik tahun } 2020 \text {, dan dianalisis menggunakan } \\
\text { metode regresi linier berganda. Hasil penelitian menemukan bahwa jumlah } \\
\text { angkatan kerja dan investasi berpengaruh signifikan dan positif terhadap PAD. } \\
\text { Berdasarkan hasil analisis determinasi diperoleh bahwa jumlah angkatan kerja } \\
\text { dan investasi memiliki kontribusi relatif besar untuk menjelaskan fluktuasi PAD, } \\
\text { meskipun masih ada sejumlah variabel independen lain yang tidak termasuk } \\
\text { dalam model penelitian ini. }\end{array}$ \\
\hline & PAD, Jumlah Angkatan Kerja, Investasi. \\
\hline
\end{tabular}

\begin{tabular}{|l|}
\hline Article Info \\
\hline Article History : \\
Received: 08 August 2021 \\
Accepted: 18 September 2021 \\
Published: January 2022 \\
\hline DOI Number: \\
10.33059/jseb.v13i1.3982 \\
How to cite : \\
Tianto, R. (2022). Pengaruh \\
jumlah angkatan kerja dan \\
investasi terhadap pendapatan \\
asli daerah. Jurnal Samudra \\
Ekonomi dan Bisnis, 13(1), \\
113-124. doi: 10.33059/jseb. \\
v13i1.3982.
\end{tabular}

Abstract

The purpose of this study is to analyze the effect of the number of labor force and investment on Regional Original Income Revenue (PAD). Provincial PAD in Indonesia has different figures for each province. Every year the PAD figure fluctuates and forms a certain pattern for each province. The number of labor force and investment is estimated to affect the amount of PAD figure. The research used data from 34 provinces in Indonesia taken from the Central Statistics Agency in 2020, and analyzed using the multiple linear regression method. The results found that the number of labor force and investment had a significant and positive effect on PAD. Based on the analysis of determination, it is found that the number of labor force and investment has a relatively large contribution to explain fluctuations in PAD, although there are still a number of other independent variables that are not included in this research model.

Keywords: Regional Original Income Reveue, Labor Number, Investment. 


\section{PENDAHULUAN}

Anggaran Pendapatan dan Belanja Daerah (APBD) merupakan suatu bentuk penyusunan anggaran rincian daftar yang dibuat secara sistematis berisi rencana penerimaan dan pengeluaran pemerintah daerah (Habiburrahman \& Imani, 2016). Sementara merujuk pada Permendagri Nomor 21 Tahun 2011, APBD adalah rencana keuangan tahunan pemerintahan daerah yang dibahas dan disetujui oleh pemerintah daerah dan DPRD serta ditetapkan dengan peraturan daerah. Kemandirian keuangan menjadi hal yang sangat penting bagi daerah terutama terkait dengan kontribusi keuangan daerah terhadap pertumbuhan ekonomi daerah itu sendiri. Besarnya kontribusi pengeluaran pemerintah daerah terhadap pertumbuhan ekonomi daerah merupakan sebuah peluang yang dapat dimanfaatkan secara optimal untuk mendorong perekonomian daerah (Gulo et al., 2017). Sehubungan dengan hal tersebut maka Pemerintah Provinsi menyusun APBD Provinsi sebagai bentuk tata perencanaan pembangunan daerah.

Tata cara penyampaian informasi keuangan daerah telah diatur Peraturan Menteri Keuangan Nomor 231/PMK.07/2020. Setiap periode tertentu pihak pemerintah melaporkan keuangan daerah ke Direktorat Jenderal Perimbangan Keuangan. Pemerintah daerah tingkat I atau bisa disebut Pemerintah Provinsi, melaporkan realisasi APBD tingkat Provinsi. Di Indonesia terdapat 34 provinsi dengan karakterisitik dari realisasi anggaran penerimaan dan pengeluaran antar pemerintah provinsi yang berbeda-beda. Menurut realisasi keuangan pemerintah provinsi terdiri dari dua komponen, yaitu penerimaan dan pengeluaran (Gorahe et al., 2014). Komponen penerimaan terdiri dari pendapatan dan pembiayaan; sementara komponen pengeluaran terdiri dari akun belanja dan pembiayaan (Harliza \& Anitasari, 2017).
Salah satu komponen yang penting dari penerimaan APBD yaitu Pendapatan Asli Daerah (PAD). PAD adalah pendapatan yang diperoleh daerah yang dipungut berdasarkan peraturan daerah sesuai dengan peraturan perundang-undangan, guna keperluan daerah yang bersangkutan dalam membiayai aktivitas nya. PAD terdiri dari pajak daerah, retribusi daerah, hasil perusahaan milik daerah dan pengelolaan kekayaan daerah yang dipisahkan, dan lain-lain pendapatan asli daerah yang sah (Bernulo et al., 2017). Semakin besarnya PAD pada APBD menunjukan kemandirian keuangan daerah semakin bagus (Wati \& Fajar, 2017). Hal tersebut menunjukan semakin kecilnya keterikatan keuangan daerah terhadap keuangan pusat. Pada umumnya apabila penerimaan APBD tidak tertutupi, maka pemerintah daerah akan menganggarkan pembiayaan untuk menutupi kekurangan tersebut. Salah satu sumber dari pembiayaan berasal dari pemerintah pusat.

Menurut Badan Pusat Statistik (BPS) tahun 2020, besar realisasi PAD provinsi di Indonesia berbeda-beda (Gambar 1). Pada tahun 2020 Provinsi DKI Jakarta merupakan provinsi dengan angka realisasi PAD yang paling tinggi yaitu Rp. 57.561.162.309.000,-Sedangkan Provinsi Sulawesi Barat adalah provinsi dengan angka realisasi PAD terendah yaitu Rp. 275.567.138.000,-. Selisih dari angka PAD provinsi tertinggi dan terendah sangat besar. Berdasarkan data BPS tahun 2020 menunjukan bahwa PAD provinsi yang terletak di Pulau Jawa cenderung lebih tinggi dibandingkan provinsi yang berada di luar Pulau Jawa. Hal tersebut membuktikan bahwa setiap daerah memiliki realisai PAD yang berbeda. Apabila dilihat dari segi waktu, besar PAD setiap provinsi di Indonesia berfluktuasi setiap tahunnya, sehingga diestimasikan bahwa PAD dipengaruhi oleh beberapa faktor. 


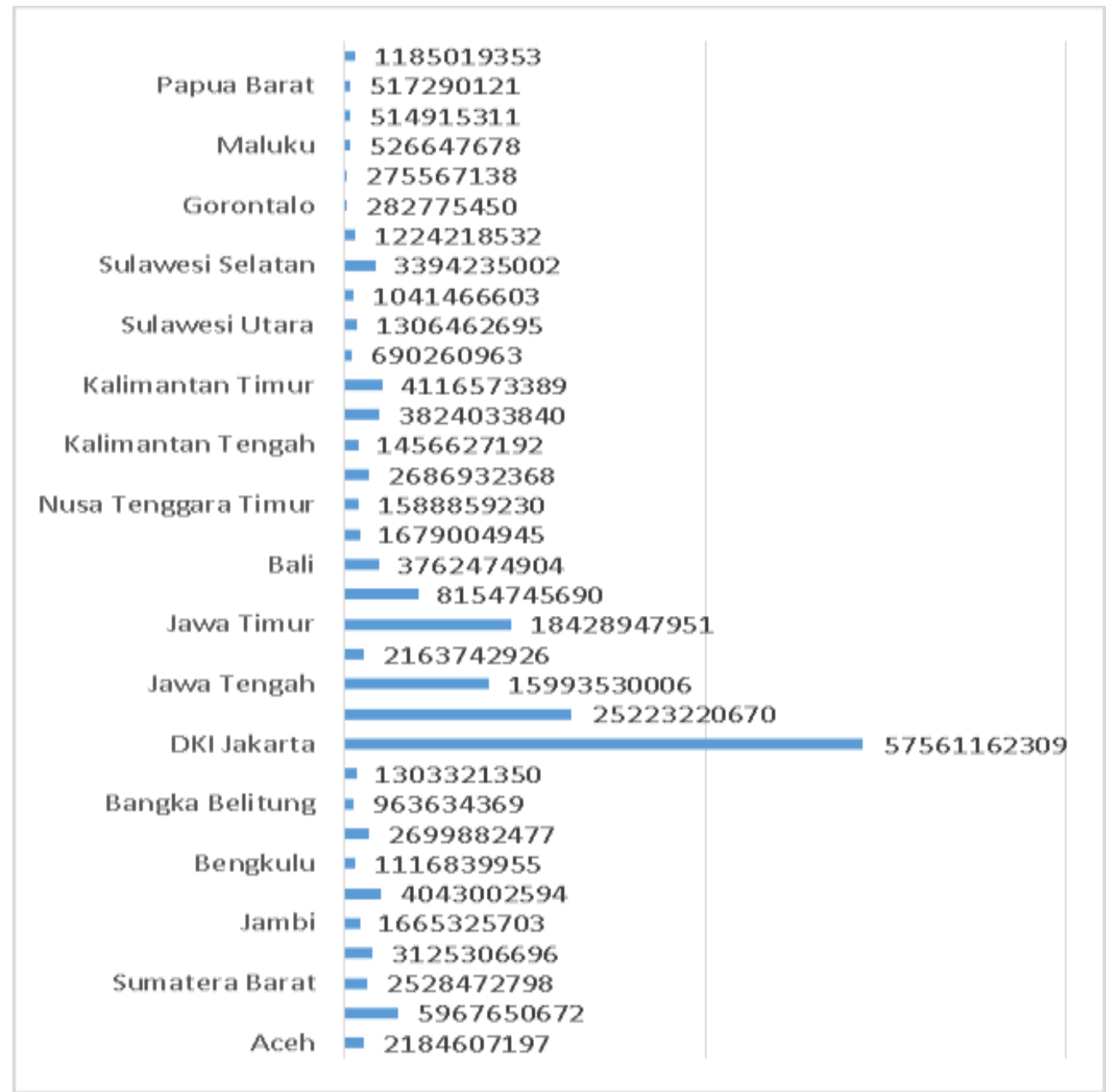

\section{Gambar 1. Pendapatan Asli Daerah Provinsi Tahun 2020 (dalam ribuan)}

Sumber: Badan Pusat Statistik, 2020.

Salah satu manfaat dari kajian PAD provinsi yaitu untuk mengetahui kondisi perekonomian setiap provinsi Indonesia. Semakin besar PAD menunjukan bahwa provinsi tersebut memiliki perekonomian yang bagus (Jolianis, 2012). Apabila PAD provinsi semakin kecil maka menunjukkan perekonomian provinsi tersebut semakin kurang bagus. Menurut beberapa kajian sebelumnya, dua faktor utama yang dinilai mempengaruhi besar kecilnya PAD secara positif dan signifikan adalah jumlah angkatan kerja dan investasi (Kurniawan et al., 2017; Muchtholifah, 2010; Ifrizal et al., 2014; Batik, 2013). Berdasarkan kajian teoritis serta penelitian terdahulu, maka penelitian ini dilakukan dengan tujuan utama menganalisis pengaruh jumlah tenaga kerja dan investasi terhadap PAD.

\section{Pendapatan Asli Daerah}

Salah satu indikator yang menunjukan kemajuan perekonomian daerah adalah Pendapatan Asli Daerah atau PAD. PAD berasal dari pendapatan pajak dan pendapatan non pajak (Nasir, 2019). Contoh dari pendapatan non pajak seperti pendapatan dari hasil badan usaha milik daerah. Berdasarkan kondisi tersebut, setiap provinsi di Indonesia karenanya memiliki karakteristik angka PAD yang berbeda-beda.

Provinsi yang memiliki sumber daya alam yang melimpah akan mengandalkan alamnya, seperti Provinsi Bali mengandalkan 
PAD pada sektor pariwisata (Suastika \& Yasa, 2017). Banyak turis yang datang berasal dari Indonesia maupun luar negeri. Kondisi tersebut mengundang investor yang mau menginvestasikan modalnya ke Provinsi Bali, baik investor lokal maupun investor asing. Investasi tersebut akan memberikan lapangan kerja bagi angkatan kerja sekitar. Secara tidak langsung aktifitas perokonomian tersebut dapat mempengaruhi besar kecilnya angka PAD.

Provinsi yang memiliki angka PAD yang tinggi menunjukkan bahwa provinsi tersebut memiliki ketergantungan yang rendah terhadap keuangan pusat (Fattah \& Irman, 2012). Berbeda dengan provinsi yang memiliki angka PAD yang rendah, ia akan cenderung membutuhkan dana lain untuk menutupi kekurangan anggaran daerah pada periode tertentu.

\section{Jumlah Angkatan Kerja}

Salah satu faktor utama yang menjadi perhatian para investor adalah ketersediaan tenaga kerja. Jumlah angkatan kerja merupakan banyaknya penduduk yang memasuki usia produktif yaitu kisaran usia 15 sampai 64 tahun (David et al., 2019). Menurut BPS, angkatan kerja yaitu penduduk usia produktif atau usia kerja 15 tahun ke atas yang bekerja, punya pekerjaan namun sementara tidak bekerja, dan pengangguran (unemployment) (www.bps.go.id).

Angkatan kerja tidak memandang status pekerjaan dari penduduk, dimana penduduk yang usianya masuk pada usia produktif dan menganggur dikategorikan sebagai angkatan kerja. Investor karenanya berfikiran dengan adanya sumber daya manusia melimpah maka mereka akan mendapatkan tenaga kerja yang bisa dibayar murah. Pada hakekatnya, semakin banyak tenaga kerja yang tersedia maka penawaran tenaga kerja akan naik; dan, semakin banyak tenaga kerja yang ditawarkan maka suatu perusahaan atau instansi akan membayar tenaga kerja tersebut dengan murah selama permintaan akan tenaga kerja masih tetap. Akan tetapi, perusahaan atau intansi tentu saja tidak akan mengambil atau merekut tenaga kerja secara serampangan. Perusahaan atau instansi akan menjadi lebih selektif dengan melimpahnya tenaga kerja tersebut.

Salah satu unsur penyumbang PAD adalah pajak (Supriadi et al., 2015). Semakin banyak tenaga kerja tersedia maka akan semakin menarik bagi investor untuk menanamkan modal, sehingga semakin banyak perusahaan ataupun instansi yang terbentuk. Hal tersebut dapat menaikan pendapatan asli daerah dari sektor pajak daerah. Pemikiran ini menunjukkan bahwa salah satu faktor yang dinilai mempengaruhi PAD adalah jumlah angkatan kerja.

Hasil penelitian Muchtholifah (2010) mendapatkan bahwa antara jumlah angkatan kerja dan PAD memiliki hubungan yang positif. Kurniawan et al. (2017) dalam studinya juga mengungkapkan hal serupa, bahwa jumlah tenaga kerja akan berdampak secara positif terhadap PAD. Kedua penelitian tersebut berargumen bahwa semakin banyak angkatan kerja yang tersedia pada suatu wilayah, maka akan besar juga nilai PAD yang diperoleh; sebaliknya, semakin kecil jumlah angkatan kerja maka akan kecil juga nilai PAD yang diperoleh.

Berdasarkan sejumlah rujukan yang telah dipaparkan, maka dinyatakan hipotesis pertama pada penelitian ini yaitu:

H1: Jumlah angkatan kerja berpengaruh positif dan signifikan terhadap PAD.

\section{Investasi}

Faktor utama kedua yang dinilai mempengaruhi PAD yaitu investasi. Menurut pengertiannya, investasi adalah penempatan sejumlah dana masa ini untuk memperoleh 
manfaat berupa pengembangan yang memberikan nilai tambah pada masa yang akan datang (Hidayati, 2017; Pardiansyah, 2017). Investasi karenanya merupakan upaya untuk mengembangkan besaran modal saat ini dan harapannya modal tersebut akan bertambah pada masa yang datang.

Pada dasarnya investasi berasal dari dua sumber, yaitu investasi dari dalam negeri dan investasi dari luar negeri (Susila et al., 2020). Investasi dari dalam negeri berasal dari investor dalam negeri; sedangkan investasi dari luar negeri berasal dari investor luar negeri. Banyak pertimbangan investor untuk menentukan instrumen investasi yang akan dipilih (Christanti \& Mahastanti, 2011). Pertimbangan utama yaitu apakah instrumen tersebut mampu memberikan keuntungan yang setinggi mungkin dengan risiko serendah mungkin. Keuntungan tinggi akan diperoleh apabila modal yang masuk akan memperoleh hasil yang maksimal.

Hasil riset milik Ifrizal et al. (2014) serta Batik (2013) menemukan bahwa investasi memberikan pengaruh terhadap PAD dalam arah yang positif. Argumentasi yang diberikan adalah apabila semakin banyak investasi yang masuk pada suatu wilayah, maka akan besar juga nilai PAD yang diperoleh; sebaliknya, apabila semakin kecil investasi yang masuk pada suatu wilayah, maka akan kecil juga nilai PAD yang diperoleh wilayah tersebut.

Berdasarkan sejumlah rujukan yang telah dipaparkan, maka dinyatakan hipotesis kedua pada penelitian ini yaitu:

H2: Investasi berpengaruh secara positif dan signifikan terhadap PAD.

\section{METODE PENELITIAN}

Data sekunder yang digunakan bersumber dari www.bps.go.id Tahun 2020. Penelitian ini menganalisis satu variabel dependen dan dua variabel independen. PAD merupakan variabel dependen (Y), dan didefinisikan sebagai pendapatan daerah yang dipungut berdasarkan peraturan daerah sesuai dengan peraturan perundang-undangan, guna keperluan daerah yang bersangkutan dalam membiayai kegiatannya. Variabel independen pertama $\left(\mathrm{X}_{1}\right)$ adalah angkatan kerja, yaitu penduduk usia produktif atau usia kerja 15 tahun ke atas yang bekerja, punya pekerjaan namun sementara tidak bekerja, maupun sebagai pengangguran. Variabel independen kedua $\left(\mathrm{X}_{2}\right)$ adalah investasi, yang didefinisikan sebagai bentuk penempatan sejumlah dana masa ini untuk memperoleh manfaat berupa pengembangan yang memberi nilai tambah pada masa yang akan datang.

\section{Metode Analisis Data}

Langkah analisis diawali dengan metode statistik deskriptif atas data. Metode deskriptif digunakan sebagai ukuran pemusatan berupa rata-rata serta ukuran dispersi berupa standard deviasi (Walpole et al., 2011).

Langkah selanjutnya adalah melakukan analisis inferensia dengan menggunakan metode regresi linier berganda (Suyitno \& Herlawati, 2015). Pada langkah ini, mulamulai dilakukan uji asumsi klasik yang meliputi uji normalitas, uji autokorelasi, uji heteroskedastisitas, serta uji multikolinieritas. Uji normalitas residual menguji agar data terdistribusi normal menggunakan kriteria Kolmogorov-Smirnov (Susila, 2020). Uji autokorelasi menggunakan uji Durbin-Watson dengan kriteria dU < nilai Durbin-Watson < 4-dU (Calen et al., 2018). Uji heteroskedastisitas menggunakan uji Harvey dengan kriteria bahwa model dinyatakan bebas dari problem ini apabila nilai $p$-value > 0,05 (Chadhir, 2015). Model regresi berganda juga harus terbebas dari problem multikolinieritas dengan kriteria bahwa nilai VIF harus lebih kecil dari 10 (Herawati et al., 2018). Proses olah data menggunakan software Minitab17. 
Tabel 1. Hasil Analisis Deskriptif

\begin{tabular}{lrrrr}
\hline \multicolumn{1}{c}{ Variabel } & \multicolumn{1}{c}{ Minimum } & \multicolumn{1}{c}{ Maksimum } & \multicolumn{1}{c}{ Rata-rata } & \multicolumn{1}{c}{ Standard Deviasi } \\
\hline PAD (dalam ribu rupiah) & 275.567 .138 & 57.561 .162 .309 & 5.388 .139 .943 & 10.723 .673 .556 \\
Jumlah Angkatan Kerja & 347.731 & 24.207 .930 & 4.065 .351 & 5.862 .857 \\
Invetasi (dalam ribu rupiah) & 347.312 .500 & 121.028 .992 .500 & 24.409 .348 .971 & 28.971 .865 .924 \\
\hline
\end{tabular}

Sumber: Data BPS (diolah), 2021.

Langkah berikutnya dalam analisis regresi berganda adalah uji $\mathrm{F}$, uji t, serta uji determinasi. Uji $\mathrm{F}$ digunakan untuk menguji pengaruh variabel-variabel independen secara simultan terhadap variabel dependen, dengan kriteria bahwa variabel independen dikatakan berpengaruh secara simultan bila nilai $p$-value kurang dari 0,05 (Marita, 2015). Uji t digunakan untuk uji parsial dimana kriteria bahwa variabel independen dikatakan berpengaruh secara signifikan apabila nilai $p$-value kurang dari 0,05 (Hendri \& Setiawan, 2017). Uji determinasi menggunakan nilai koefisien $R$ Squared $\left(\mathrm{R}^{2}\right)$, yang menunjukan seberapa besar kontribusi variabel independen dapat menjelaskan perubahan-perubahan yang bisa terjadi atas variabel dependen.

\section{HASIL ANALISIS}

\section{Analisa Statistik Deskriptif}

Tujuan dari analisa statistik deskritif yaitu untuk mengetahui karakteristik data penelitian. Untuk memudahkan karakterisasi data PAD, jumlah angkatan kerja, serta investasi, maka dirangkum dalam Tabel 1.

Berdasarkan Tabel 1 diketahui bahwa PAD tertinggi pada tahun 2020 adalah sebesar Rp. 57.561.162.309.000,-. Dihubungkan pada Gambar 1, angka tertinggi itu merupakan PAD dari Provinsi DKI Jakarta. Kondisi ini disadari karena DKI Jakarta merupakan pusat perekonomian Indonesia dengan banyak perusahaan besar maupun instansi pemerintah yang memiliki kantor pusat di wilayah tersebut sehingga membuat pendapatan daerah Provinsi DKI Jakarta paling tinggi di Indonesia pada tahun 2020. Pendapatan tersebut diperoleh dari sektor pajak maupun non pajak.

Sementara itu, PAD terendah yang teridentifikasi pada Tabel 1 adalah sebesar Rp. 275.567.138.000,-. Dikaitkan dengan Gambar 1, angka terendah itu merupakan PAD milik Provinsi Sulawesi Barat. Dengan demikian, diperlukan stimulus untuk Provinsi tersebut agar dapat meningkatkan angka PAD. Stimulus tersebut bisa berupa upaya mengundang investor agar mau melakukan investasi dana pada provinsi tersebut. Selain itu, pemerintah provinsi itu juga harus memperhatikan peraturan daerah terkait penanaman modal sehingga implementasinya tidak menyulitkan bagi para investor.

Tabel 1 juga menyatakan bahwa nilai rata-rata PAD provinsi pada tahun 2020 yaitu sebesar Rp. 5.388.139.943.000,-. Berdasarkan angka tersebut, dihubungkan pada Gambar 1, maka dapat diidentifikasi lima provinsi di Pulau Jawa yang memiliki nilai PAD di atas rata-rata, dan hanya Provinsi Daerah Istimewa Yogyakarta yang memiliki PAD dibawah rata-rata. Kelima provinsi tersebut adalah Provinsi DKI Jakarta di urutan pertama, berikutnya yaitu Provinsi Jawa Barat, di urutan ketiga adalah Provinsi Jawa Timur, lalu diikuti oleh Provinsi Jawa Tengah, dan posisi terakhir yaitu Provinsi Banten.

Lebih jauh, berdasarkan Tabel 1 dan Gambar 1, teridentifikasi hanya terdapat satu provinsi di luar Pulau Jawa yang memiliki PAD diatas rata-rata yaitu Provinsi Sumatera Utara, sedangkan provinsi lainnya memiliki angka PAD dibawah rata-rata PAD provinsi. Angka-angka tersebut menunjukan bahwa 
pembangunan ekonomi di Indonesia belum merata, dimana perekonomian Indonesia masih terpusat pada provinsi-provinsi yang berada di Pulau Jawa.

Berikutnya, berdasarkan keterkaitan antara Tabel 1 dan Gambar 1, diidentifikasi jumlah angkatan kerja tertinggi yaitu sebesar 24.207.930 orang merupakan jumlah yang dimiliki Provinsi Jawa Barat. Sedangkan angka terendah dari jumlah angkatan kerja pada tahun 2020 yaitu sebesar 347.731 orang merupakan capaian dari Provinsi Kalimantan Utara. Hal ini disadari karena Provinsi Kalimantan Utara merupakan provinsi yang terbentuk pada tahun 2013 sehingga dinilai memiliki jumlah penduduk relatif rendah dibandingkan provinsi lainnya. Angka ratarata dari jumlah angkatan kerja pada tahun 2020 adalah sebesar 4.065.351 orang.

Jumlah investasi di Indonesia pada tahun 2020 teridentifikasi melalui Tabel 1 sebesar Rp. 829.917.865.000.000,-. Investasi tersebut merupakan akumulasi dana dari dalam dan luar negeri. Pada Tabel 1, nilai investasi tertinggi menurut provinsi adalah sebesar Rp. 121.028.992.500.000,- yang dicapai oleh Provinsi Jawa Barat; sementara nilai investasi paling rendah pada tahun 2020 yaitu sebesar Rp. 347.312.500.000,- dicapai oleh Provinsi Sulawesi Barat. Nilai rata-rata investasi provinsi pada tahun 2020 sebesar Rp. 24.409.348.971.000,--.

\section{Uji Asumsi Klasik}

Pada analisis regresi linier berganda untuk penelitian ini menggunakan data transformasi Logaritma Natural (Ln), karena upaya uji pertama terkait problem normalitas diperoleh hasil residual yang tidak memenuhi asumsi klasik berdistribusi normal apabila menggunakan data asli. Pada saat upaya berikutnya, uji Kolmogorov-Smirnov menggunakan data yang sudah ditransformasi Ln memperoleh hasil titik-titik residual yang mengikuti garis diagonal dengan nilai $p$-value lebih dari 0,05 ; sehingga dinyatakan residual sudah memenuhi asumsi berdistribusi normal.

Berikutnya, hasil uji autokorelasi menggunakan uji Durbin-Watson diperoleh nilai sebesar 2,03. Untuk nilai tabel DurbinWatson dengan jumlah observasi sebanyak 34 dan variabel independen sebanyak 2 buah, diperoleh nilai $\mathrm{dL}$ sebesar 1,33 dan nilai $\mathrm{dU}$ sebesar 1,58. Dengan demikian, nilai DurbinWatson memenuhi kondisi 1,58 $<2,03<2,42$ sehingga disimpulkan bahwa model regresi penelitian terbebas dari problem autokorelasi.

Untuk uji heteroskedasitas menggunakan uji Harvey diperoleh nilai $p$-value sebesar 0,53 . Nilai tersebut adalah lebih besar dari 0,05 yang berarti dapat disimpulkan bahwa model regresi dalam penelitian ini sudah terbebas dari problem heteroskedasitas. Hasil uji multikolinieritas juga memperoleh bahwa model regresi penelitian ini sudah terbebas dari problem ini dimana nilai VIF kurang dari 10 untuk jumlah angkatan kerja maupun investasi.

Berdasarkan perolehan hasil uji asumsi klasik secara keseluruhan maka diperoleh hasil yang sudah memenuhi semua asumsi yang disyaratkan. Dengan demikian, model regresi dalam penelitian ini dapat digunakan untuk keperluan analisis lebih lanjut.

\section{Analisis Regresi Linier Berganda}

Proses analisis regresi linier berganda dalam penelitian ini menggunakan bantuan software Minitab 17. Hasil analisis pertama ditunjukkan dalam Tabel 2. Berdasarkan tabel tersebut dapat dibentuk model regresi linier berganda yang digunakan dalam penelitian ini mengenai pengaruh dari jumlah angkatan kerja dan investasi terhadap PAD adalah sebagai berikut.

$$
\operatorname{Ln}\left(Y_{\mathrm{i}}\right)=1,90+0,82 \operatorname{Ln}\left(X_{1, i}\right)+0,26 \operatorname{Ln}\left(X_{2, i}\right)+\varepsilon_{\mathrm{i}}
$$


Tabel 2. Hasil Analisis Regresi dan Uji t

\begin{tabular}{lcccc}
\hline \multicolumn{1}{c}{ Variabel } & Koefisien & SE Koefisien & t-value & $p$-value \\
\hline Konstanta & 1,90 & 2,04 & 0,93 & 0,36 \\
$\operatorname{Ln}\left(X_{1}\right)$ & 0,82 & 0,12 & 6,73 & 0,00 \\
$\operatorname{Ln}\left(X_{2}\right)$ & 0,26 & 0,09 & 2,73 & 0,01 \\
\hline
\end{tabular}

Sumber: Data sekunder (diolah), 2021.

Tabel 3. Hasil Uji F

\begin{tabular}{lccccc}
\hline \multicolumn{1}{c}{ Source } & df & Adj SS & Adj MS & F-Value & P-Value \\
\hline Regression & 2 & 40,63 & 20,31 & 74,75 & 0,00 \\
Ln_X & 1 & 12,32 & 12,32 & 45,34 & 0,00 \\
Ln_X & 1 & 2,03 & 2,03 & 7,48 & 0,01 \\
Error & 31 & 8,43 & 0,27 & & \\
Total & 33 & 49,05 & & & \\
\hline
\end{tabular}

Sumber: Data sekunder (diolah), 2021.

Berdasarkan model tersebut diperoleh nilai koefisien regresi bagi masing-masing variabel jumlah angkatan kerja $\left(\mathrm{X}_{1}=0,82\right)$ serta untuk variabel investasi $\left(X_{2}=0,26\right)$ yaitu positif. Dengan demikian, dinyatakan bahwa pengaruh dari kedua variabel tersebut terhadap PAD bersifat positif. Artinya, apabila salah satu dari kedua variabel independen itu mengalami kenaikan, dengan asumsi bahwa variabel-variabel independen yang lain tidak mengalami perubahan, maka nilai PAD yang diperoleh suatu provinsi juga akan mengalami kenaikan. Sebaliknya, jika salah satu dari kedua variabel independen itu mengalami penurunan, dengan asumsi bahwa variabel-variabel independen yang lain tidak mengalami perubahan, maka capaian nilai PAD provinsi juga mengalami penurunan.

Berdasarkan Tabel 2 didapati variabel jumlah angkatan kerja $\left(t_{1}=6,73 ; p\right.$-value $=$ $0,00)$ memiliki nilai $p$-value $<0,05$, sehingga dinyatakan bahwa jumlah angkatan kerja memiliki pengaruh parsial secara signifikan terhadap PAD. Bila dikombinasikan dengan nilai koefisien regresi yang telah diperoleh sebelumnya, maka dapat disimpulkan bahwa hipotesis pertama $\left(\mathrm{H}_{1}\right)$ bisa dibuktikan secara empiris dalam penelitian ini.
Hasil uji t untuk variabel independen kedua pada Tabel 2 menunjukkan bahwa variabel investasi $\left(t_{2}=2,73 ; p\right.$-value $\left.=0,01\right)$ memiliki nilai $p$-value $<0,05$, sehingga dinyatakan bahwa investasi juga memiliki pengaruh parsial secara signifikan terhadap PAD. Bila dikombinasikan dengan nilai koefisien regresi yang diperoleh sebelumnya, maka dapat disimpulkan bahwa hipotesis kedua $\left(\mathrm{H}_{2}\right)$ juga terbukti secara empiris.

Hasil analisis berikutnya berupa uji $\mathrm{F}$ dirangkum dalam Tabel 3. Berdasarkan tabel tersebut diperoleh nilai $\mathrm{F}$ sebesar 74,75 dan $p$ value sebesar 0,00 . Karena perolehan nilai $p$ value kurang dari 0,05 maka dapat disebutkan bahwa jumlah angkatan kerja dan investasi secara simultan berpengaruh signifikan terhadap PAD.

Terakhir, berdasarkan model regresi linier berganda yang terbentuk, diperoleh nilai koefisien determinasi $\left(\mathrm{R}^{2}\right)$ sebesar 0,8282. Angka ini menyatakan informasi bahwa jumlah angkatan kerja dan investasi dapat berkontribusi menjelaskan fluktuasi dari PAD sebesar 82,82 persen; sementara sisanya sebesar 17,18 persen dijelaskan oleh variabelvariabel independen lain yang tidak tercakup dalam model penelitian ini. 


\section{Pembahasan}

Berdasarkan hasil analisis yang telah dilakukan, didapatkan informasi bahwa PAD provinsi tertinggi di Indonesia tahun 2020 yaitu Provinsi DKI Jakarta, dan yang terendah adalah Provinsi Sulawesi Barat. Angka PAD dipengaruhi oleh besar kecilnya angka dari jumlah angkatan kerja dan investasi. Semakin besar jumlah angkatan kerja dan investasi cenderung akan didapat nilai PAD yang besar juga. Pada dasarnya, investor akan tertarik terhadap provinsi yang memiliki jumlah angkatan kerja yang banyak dikarenakan melimpahnya tenaga kerja tersebut membuat imbalan tenaga kerja yang diberikan akan lebih rendah dibandingkan provinsi yang memiliki tenaga kerja yang sedikit. Selain itu, msuknya dana investasi investor akan menghidupkan kegiatan ekonomi di provinsi bersangkutan. Aktifitas ekonomi itu dapat menaikan pendapatan pajak maupun non pajak, sehingga nilai PAD provinsi juga akan turut mengalami kenaikan.

\section{Pengaruh Jumlah Angkatan Kerja atas PAD}

Berdasarkan hasil analisis diperoleh kesimpulan bahwa jumlah angkatan kerja memiliki pengaruh signifikan terhadap PAD. Besaran koefisien dari jumlah angkatan kerja yaitu bernilai positif artinya jumlah angkatan kerja berpengaruh positif terhadap PAD; atau bahwa hipotesa pertama penelitian dapat dibuktikan.

Hasil dari penelitian ini mendukung hasil studi milik Muchtholifah (2010) serta Kurniawan et al. (2017) yang menemukan bahwa jumlah angkatan kerja bepengaruh secara signifikan dan positif terhadap PAD. Berdasarkan hasil penelitian ini dan penelitian sebelumnya maka dapat disimpulkan bahwa jika ingin menaikkan PAD, maka pemerintah harus mempertimbangkan jumlah tenaga kerja yang tersedia. Hasil penelitian ini menyatakan bahwa semakin banyak tenaga kerja yang tersedia maka akan menaikan PAD. Begitu juga sebaliknya, jika semakin sedikit jumlah tenaga kerja yang tersedia maka berdampak akan menurunkan PAD.

\section{Pengaruh Investasi atas PAD}

Berdasarkan hasil analisis diperoleh bahwa investasi memiliki pengaruh signfikan terhadap PAD. Besar koefisien dari investasi bernilai positif, artinya investasi memiliki pengaruh positif terhadap PAD. Dengan demikian, dapat disimpulkan bahwa hipotesa kedua pada penelitian ini dapat dibuktikan.

Hasil penelitian ini mendukung hasil studi milik Ifrizal et al. (2014) serta Batik (2013) yang menemukan bahwa investasi berpengaruh signifikan dan positif terhadap PAD. Dengan demikian, selain faktor jumlah tenaga kerja sebagai strategi untuk menaikkan PAD provinsi, pemerintah juga harus mempertimbangkan faktor investasi di dalam penyusunan strategi tersebut. Berdasarkan hasil penelitian ini dan penelitian sebelumnya disimpulkan bahwa apabila pemerintah ingin menaikan PAD, pemerintah harus mempertimbangkan investasi yang masuk. Semakin banyak investasi yang masuk maka akan menaikkan PAD; sebaliknya, semakin sedikit investasi yang masuk maka akan menurunkan PAD. Oleh sebab itu, pemerintah daerah yang bersangkutan harus bisa membuat investor tertarik untuk berinvestasi pada provinsi yang dipimpinnya. Pemerintah sebaiknya berupaya menetapkan regulasi-regulasi terkait seperti mengenai proses investasi, bersama dengan peraturan ketenagakerjaan daerah, sedemikian rupa sehingga menarik minat para investor untuk bersedia mempertimbangkannya.

\section{SIMPULAN}

Berdasarkan hasil analisis yang ditemukan, disimpulkan bahwa jumlah tenaga kerja serta investasi memiliki pengaruh signifikan dan positif terhadap PAD. Hal ini berarti 
apabila besaran jumlah tenaga kerja ataupun investasi mengalami kenaikan maka akan terjadi pula kenaikan PAD provinsi. Atau sebaliknya, apabila besaran jumlah tenaga kerja ataupun investasi mengalami kenaikan maka akan terjadi pula kenaikan PAD pada provinsi yang bersangkutan.

Hasil-hasil penelitian ini berkontribusi memperkuat teori bahwa jumlah angkatan kerja dan investasi bepengaruh signifikan dan positif terhadap PAD. Sementara itu, kontribusi praktis penelitian ini yaitu memberikan masukan kepada pemerintah terkait dalam pengambilan kebijakan-kebijakan yang ditujukan untuk mengoptimalkan PAD.

Keterbatasan utama dalam penelitian ini adalah bahwa data yang dianalisis menggunakan data tipe transformasi. Hal ini dikarenakan apabila menggunakan data asli tanpa ditransformasi terlebih dahulu saat menjalankan proses analisis, maka diperoleh hasil asumsi residual berdistribusi normal tidak terpenuhi. Peneliti berikutnya sebaiknya berupaya menggunakan metode analisis berbeda agar permasalahan ini tidak terjadi.

\section{REFERENSI}

Badan Pusat Statistik. (2020). Statistik keuangan pemerintah provinsi 20172020. Badan Pusat Statistik Republik Indonesia. Retrieved from https://www. bps.go.id/publication/2020/12/21/37736 50f41abfef7688f6f79/statistikkeuangan-pemerintah-provinsi-20172020.html.

Batik, K. (2013). Analisis pengaruh investasi, PDRB, jumlah penduduk, penerimaan pembangunan, dan inflasi terhadap pendapatan asli daerah (PAD) di Kabupaten Lombok Barat. Jurnal Ekonomi Pembangunan, 11(1), 115140. doi: 10.22219/jep.v11i1.3735.

Bernulo, L. L. D., Masinambow, V. A. J., \& Wauran, P. C. (2017). Analisis pendapatan asli daerah (PAD) di Kota Jayapura. Jurnal Berkala Ilmiah Efisiensi, 17(1), 22-33. Retrieved from https://ejournal.unsrat.ac.id/index.php/j bie/article/view/14580/14151.

Calen, Ade, S., Rosmaneliana, D., \& Evadine, R. (2018). The impact of return on equity (ROE) and debt to equity ratio (DER) Toward change in profit on the plantation company registered on BEI. International Journal of Management Sciences and Business Research, 7(2), 204-212. doi: 10.31219/osf.io/5adfh.

Chadhir, M. (2015). Analisis faktor-faktor yang mempengaruhi ekspor teh Indonesia ke negara Inggris 1979-2012. Economics Development Analysis Journal, 4(3), 292-300. doi: 10.15294/ edaj.v4i3.14836.

Christanti, N., \& Mahastanti, L. A. (2011). Faktor-faktor yang dipertimbangkan investor dalam melakukan investasi. Jurnal Manajemen Teori dan Terapan, 4(3), 37-51. doi: 10.20473/jmtt.v4i3. 2424.

David, Y. B., Engka, D. S. M., \& Sumual, J. I. (2019). Pengaruh angkatan kerja bekerja dan jumlah penduduk terhadap pengangguran di Sulawesi Utara. Jurnal EMBA, 7(8), 3389-3398. doi: 10.35794/emba.v7i3.24276.

Fattah, S., \& Irman. (2012). Analisis ketergantungan fiskal pemerintah daerah di Provinsi Sulawesi Selatan pada era otonomi daerah. Prosiding Seminas Competitive Advantage, 1(2), 1-8. Retrieved from https://www.test. journal.unipdu.ac.id/index.php/seminas/ article/view/138/87.

Gorahe, I. A. M., Masinambow, V., \& Engka, D. (2014). Analisis belanja daerah dan faktor-faktor yang mempengaruhinya di Provinsi Sulawesi Utara. Jurnal Berkala Ilmiah Efisiensi, 14(3), 1-12. 
Retrieved from https://ejournal.unsrat. ac.id/index.php/jbie/article/view/5650/5 182.

Gulo, A. K., Zamzani, \& Bhakti, A. (2017). Dampak alokasi belanja langsung terhadap ketimpangan ekonomi wilayah (Studi kasus Provinsi Sumatera Utara, Provinsi Jambi, dan Provinsi Bengkulu). Jurnal Paradigma Ekonomi, 12(2), 57-66. Retrieved from https://online-journal.unja.ac.id/ paradigma/article/view/3941/8499.

Habiburrahman \& Imani R. (2016). Analisis anggaran pendapatan dan belanja daerah (APBD) Kota Bandar Lampung. Jurnal Manajemen dan Bisnis, 6(2), 120-134. Retrieved from http://jurnal. ubl.ac.id/index.php/jmb/article/view/83 4/846.

Harliza, T., \& Anitasari, M. (2017). Analisis belanja daerah kabupaten/kota di Bengkulu. Ekombis Review: Jurnal Ekonomi dan Bisnis, 5(2), 133-140. Retrieved from https://jurnal.unived.ac. id/index.php/er/article/view/382.

Hendri \& Setiawan, R. (2017). Pengaruh motivasi kerja dan kompensasi terhadap kinerja karyawan di PT. Samudra Bahari Utama. Jurnal AGORA, 5(1), 18. Retrieved from http://publication. petra.ac.id/index.php/manajemenbisnis/article/view/6098/5596.

Herawati, N., Nisa, K., Setiawan, E., Nusyirwan \& Tiryono. (2018). Regularized multiple regression methods to deal with severe multicollinearity. International Journal of Statistics and Applications, 8(4), 167172. doi: 10.5923/j.statistics. 201808 04.02 .

Hidayati, A. N. (2017). Investasi: Analisis dan relevansinya dengan ekonomi Islam. Jurnal Ekonomi Islam, 8(2), 227-242. Retrieved from https://jurnal. yudharta.ac.id/v2/index.php/malia/articl e/download/598/489.

Ifrizal, Darmawanis \& Sulaiman. (2014). Pengaruh investasi terhadap pendapatan asli daerah serta dampaknya pada kemampuan daerah membiayai belanja pegawai (Studi pada pemerintah kabupaten/kota di Provinsi Aceh). Jurnal Akuntansi, 3(2), 33-41. Retrieved from http://www.jurnal. unsyiah.ac.id/JAA/article/view/4422/ 3803.

Jolianis. (2012). Analisis perekonomian daerah dan pendapatan asli daerah kabupaten/kota di Provinsi Sumatera Barat. Economica: Journal of Economic and Economic Education, 1(1), 32-43. Retrieved from http:// ejournal.stkip-pgri-sumbar.ac.id/ index.php/economica/article/viewFile/1 03/696.

Kurniawan, A. I., Militina, T., \& Suharto, R. B. (2017). Pengaruh investasi swasta dan pengeluaran pemerintah serta tenaga kerja terhadap pendapatan asli daerah dan pertumbuhan ekonomi. Jurnal INOVASI, 13(2), 68-77. Retrieved from http://journal.feb. unmul.ac.id/index.php/INOVASI/articl e/view/2453/237.

Marita, W. E. (2015). Pengaruh struktur organisasi dan ukuran perusahaan terhadap penerapan business entity concept. Jurnal AKRUAL, 7(1), 18-40. doi: 10.26740/jaj.v7n1.p18-40.

Muchtholifah. (2010). Pengaruh produk domestik regional bruto (PDRB), inflasi, investasi industri dan jumlah tenaga kerja terhadap pendapatan asli daerah (PAD) di Kota Mojokerto. Jurnal Ilmu Ekonomi Pembangunan, 1(1), 1-10. Retrieved from http:// eprints.upnjatim.ac.id/3027/1/jiep12jun 010.pdf. 
Nasir, M. S. (2019). Analisis sumber-sumber pendapatan asli daerah setelah satu dekade otonomi daerah. Jurnal Dinamika Ekonomi Pembangunan, 2(1), 30-45. doi: 10.14710/jdep.2.1. 30-45.

Pardiansyah, E. (2017). Investasi dalam perspektif ekonomi Islam: Pendekatan teoritis dan empiris. Economica: Jurnal Ekonomi Islam, 8(2), 337-373. doi: 10.21580/economica.2017.8.2.1920.

Suastika, I. G. Y., \& Yasa, I. N. M. (2017). Pengaruh jumlah kunjungan wisatawan, lama tinggal wisatawan dan tingkat hunian hotel terhadap pendapatan asli daerah dan kesejahteraan masyarakat pada kabupaten/kota di Provinsi Bali. E-Jurnal Ekonomi Pembangunan Universitas Udayana, 6(7), 1332-1362. Retrieved from https://ojs.unud.ac. id/index.php/eep/article/view/29349/18 751.

Supriadi, D. R., Dwiatmanto \& Karjo, S. (2015). Kontribusi pajak hiburan dalam meningkatkan pendapatan asli daerah (PAD) di Kota Malang (Studi kasus dinas pendapatan daerah Kota Malang). Jurnal Perpajakan (JEJAK), 1(1), 1-9. Retrieved from http://perpajakan. studentjournal.ub.ac.id/index.php/perpa jakan/article/view/90/80.
Susila, M. R. (2020). Pengaruh hari raya Idul Fitri terhadap inflasi di Indonesia dengan pendekatan ARIMAX (Variasi kalender). Jurnal Barekeng, 14(3), 367376. doi: 10.30598/barekengvol14 iss3pp369-376.

Susila, M. R., Putri, R. C., \& Arini, D. (2020). Pemodelan regresi spasial investasi luar negeri yang masuk ke Indonesia. Jurnal Barekeng, 14(4), 543-556. doi: 10. 30598/barekengvol14iss4pp543-556.

Suyitno, P. P., \& Herlawati. (2015). Metode regresi linier berganda kualitas super member supermall terhadap peningkatan jumlah pengunjung pada Supermall Karawang. Jurnal Bina Insani, 2(2), 101-116. Retrieved from http://ejournal-binainsani.ac.id/ index.php/BIICT/article/view/789/635.

Walpole, R. E., Myers, R. H., Myers, S. L., \& Ye, K. (2011). Probability \& statistics for engineers \& scientist ( $9^{\text {th }}$ edition). Pearson Education.

Wati, M. R., \& Fajar, C. M. (2017). Pengaruh pendapatan asli daerah dan dana perimbangan terhadap belanja daerah Kota Bandung. Jurnal Kajian Akuntansi, 1(1), 63-76. Retrieved from http://jurnal.ugj.ac.id/index.php/jka/arti cle/view/445/323. 